\title{
The redlining of harm reduction programs
}

$\mathrm{F}$ irst came an assault on Vancouver, British Columbia's safe injection site. That was followed by the axing of safe tattooing programs in prisons (www.cmaj.ca /lookup/doi/10.1503/cmaj.070017), as well as opposition to needle exchange and safe sex programs. Meanwhile, federal funding for drug substitution programs has quietly dried up.

Now, a suite of new drug laws working their way through Parliament has everyone forecasting that judges will have little option but to throw a whole lot of drug users into the hoosegow, where rates of HIV and hepatitis $\mathrm{C}$ infection are exponentially greater than among the general population (www.csc-scc.gc.ca/text/rsrch /reports/r211/r211-eng.shtml).

The pattern is self-evident, public health advocates say. To wit: harm reduction programs are anathema to Prime Minister Stephen Harper's governing Conservative party.

"Ottawa's new approach is to criminalize what should still be seen as a health issue," says Cathy McIsaac, executive director of Direction 180, a methadone clinic in Halifax, Nova Scotia. "You can't even use the term harm reduction anymore when applying for federal funding. The taps have been turned off."

And an already grim situation will only get grimmer once the government's omnibus crime legislation is passed and the raft of new prisons are built to house the anticipated influx of inmates, says Dr. Peter Ford, a Manitoulin Island, Ontario-based physician who oversees HIV treatment in federal prisons in Ontario. "We are going to see a lot of new people in the jails, which are already overcrowded and which already serve as one of Canada's biggest hepatitis $\mathrm{C}$ reservoirs. This is going to get a lot worse."

Moreover, the omnibus legislation will only embolden efforts like one which recently saw community groups in Victoria, BC, force the discontinua-

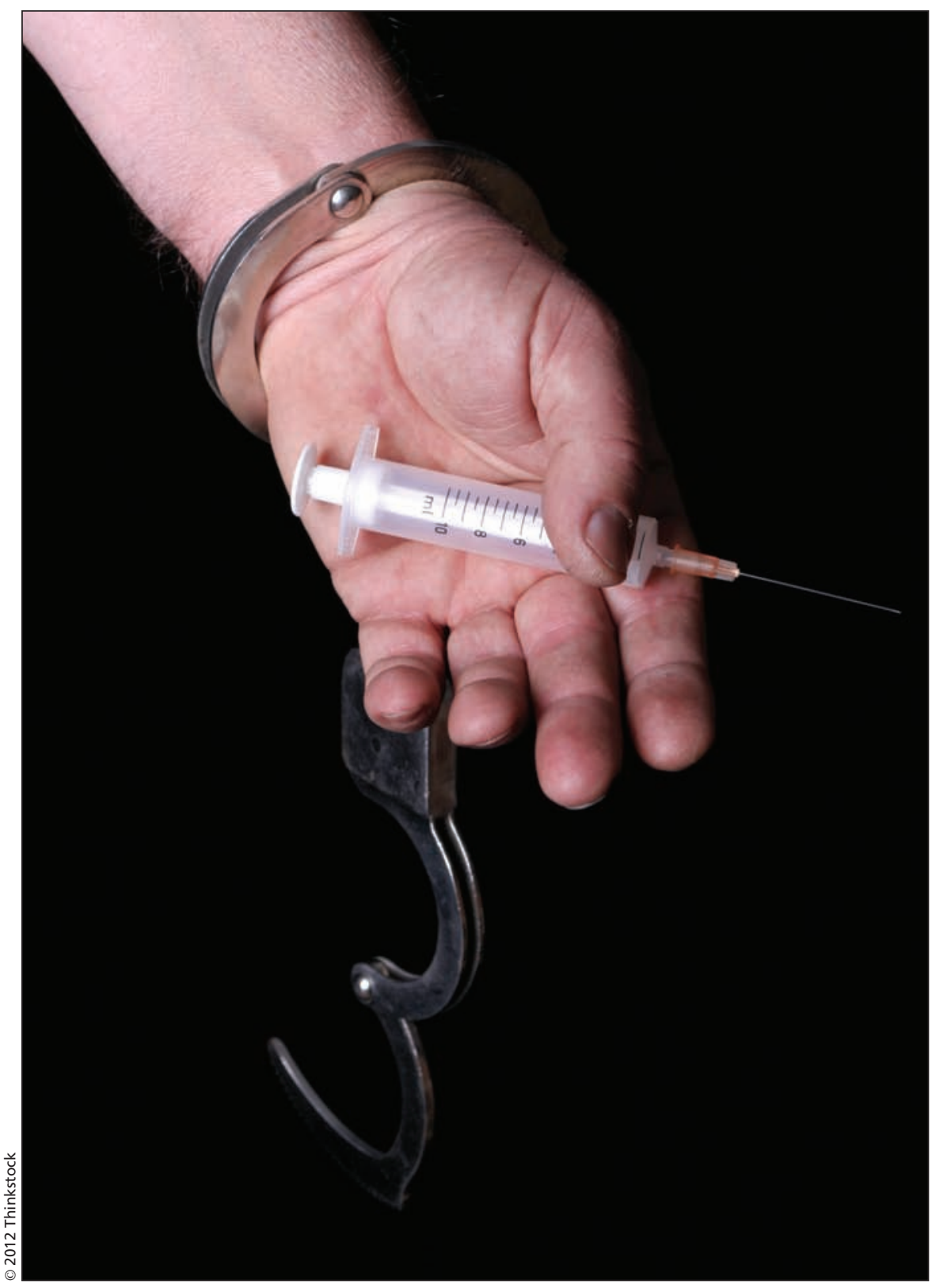

With omnibus federal crime legislation predicted to result in an influx of inmates into prisons, where drug use is common, experts fear a wave of hepatitis C and HIV incidence will ensue.

tion of the city's needle exchange program, says Rob Boyd, director of the Oasis Program at the Sandy Hill Community Health Centre in Ottawa, Ontario, which provides health services for substance abusers.

"The new drug legislation will further stigmatize an already stigmatized group," he warns. "It will severely impede their ability to recover from their substance use disorder and it will put people in the highest risk environment of all, prisons."

Public health advocates say the assault on harm reduction is a case of the Harper government essentially 
heaving hunks of red meat to core Conservatives. The reduction in support for harm reduction programs began with nonrenewal of funding for the supervised injection site in Vancouver, and dithering on the extension of its exemption from drug law (www .cmaj.ca/lookup/doi/10.1503/cmaj .061209) and even featured assertions by a Conservative minister that doctors who support safe injection sites are unethical (www.cmaj.ca/lookup /doi/10.1503/cmaj.081317).

At that time, says Monique DoolittleRomas, executive director of the Canadian AIDS Society, the Conservative government also essentially withdrew federal support from the 2005 National Framework for Action to Reduce the Harms Associated with Alcohol and Other Drugs and Substances in Canada (www.nationalframework-cadrenational .ca/), which had been developed as a roadmap for addressing problematic substance abuse and featured a national treatment strategy (www.nationalframe work-cadrenational.ca/uploads/files/TWS _Treatment/nts-report-eng.pdf).

Simultaneously, the Canadian government began backing away from any manner of harm reduction programming as a component of international drug control strategies, says Mike Trace, chair of the International Drug Policy Consortium, a London, United Kingdom-based group of 82 nongovernmental organizations and professional associations.

The final blow was delivered by Harper himself in the form of the 2007 National Anti-Drug Strategy (www .nationalantidrugstrategy.gc.ca/nads -sna.html), which he called a bid to break "Canada's drug habit," but which the Toronto, Ontario-based Centre for Addiction and Mental Health decried as having "purposefully left out" harm reduction (www.camh.net/Public_policy /NADS\%20Response\%20Final\%2020 08.pdf).

The upshot is that harm reduction has been shoved into "the shadows," says an Alberta official, who requests anonymity for fear of federal government reprisal. "After 20 years in the harm reduction field I cannot even call my work by its name. It makes us feel deceitful and criminal."

Federal funding for communitybased harm reduction initiatives has evaporated, adds Susan Shepherd, manager of the Toronto's Drug Strategy Secretariat. As a consequence, front-line programs, such as the Toronto-based Supporting Communities Partnership Initiative, which once distributed federal monies to needle exchange programs in 15 cities, has had to be remodelled to exclude harm reduction, says Holly Kramer, coordinator of Toronto's Harm Reduction Task Force.

The federal assault has been particularly acute on harm reduction programs in prisons, argues Anne Marie diCenso, executive director of the Toronto-based Prisoners HIV/AIDS Support Action Network. Among the casualties was a $\$ 600000$ sterile tattooing pilot project. While former public safety minister Stockwell Day dismissed it as a waste of tax dollars that wasn't "demonstrably effective," Chief Public Health Officer of Canada Dr. David Butler-Jones said it wasn't given enough time to demonstrate its worth (www.cmaj.ca /lookup/doi/10.1503/cmaj.070017).

Yet, the most severe consequences of the move away from harm reduction programs may ultimately fall on the Aboriginal community.

In recent talks on renewal of the long-standing National Native Alcohol and Drug Abuse program, Health Canada has substituted "secondary risk reduction" (a term usually applied to HIV management) for harm reduction, notes Carol Hopkins, executive director of the Muskoday, Saskatchewan-based National Native Addictions Partnership Foundation. While the aim will be to expand community-level treatment, the services to be provided will be targeted at "reducing harms as a result, rather than as an approach."

"Harm reduction has become a rather polarized term," concedes Rebecca Jesseman, research and policy analyst with the Canadian Centre on Substance Abuse, which once was to have been a major player in implementing the scuttled national harm reduction framework.

Health Canada spokesperson Olivia Caron says the framework "does not guide Health Canada policy or program funding" but claims the department nevertheless adopted some of its precepts "by investing in health promotion and prevention projects aimed at discouraging the initiation of illicit drug use and preventing the progression to more frequent or regular use among youth."

And while the National Native Alcohol and Drug Abuse Program may not specifically support harm reduction, it doesn't preclude such services as access to "opiate replacement programs, such as methadone maintenance therapy, as prescribed by physicians," she adds. - Paul Christopher Webster, Toronto, Ont.

CMAJ 2012. DOI:10.1503/cmaj.109-4054 